\title{
Jacek Piekarski, Liliana Tomaszewska, Agnieszka Głowala (red.), „Edukacja jako całożyciowe doświadczenie”, Wydawnictwo Państwowej Wyższej Szkoły Zawodowej w Płocku, Płock 2012
}

Recenzowana monografia podkreśla i przedstawia wartość oraz znaczenie edukacji, rozwoju osobowego w życiu każdego człowieka, a zwłaszcza nauczyciela. Całość tomu składa się z trzech części: Drogi edukacyjne - drogi życiowe, Edukacja całożyciowa - edukacja ustawiczna, Uczenie się w biografii - ludzie i instytucje. Każda z tych części zawiera kilka referatów. Książkę otwiera wstęp Liliany Tomaszewskiej, który daje ogólny wgląd w tematykę recenzowanej monografii.

Pierwszą część rozpoczyna referat Jacka Piekarskiego, który został zatytułowany Biografia zawodowa - między kreacja a kontrola. Przedstawia on rozważania na temat biograficznego aspektu uczenia się nauczycieli w połączeniu z praktyką zawodową oraz omawia warunki tego procesu. Referat Marii Szyszkowskiej Rola nauczyciela w edukacji całożyciowej i płynace stąd postulaty nauczania mądrości przedstawia szeroko pojętą rolę nauczycieli w procesie kształcenia całożyciowego, wskazując na ich szczególną misję, między innymi w uzupełnianiu braków w wychowaniu w rodzinie oraz zaszczepianiu tolerancji. W kolejnej publikacji Czego uczq badania dróg edukacyjnych? Olga Czerniawska zaprezentowała analizę ścieżek edukacyjnych począwszy od lat osiemdziesiątych, andragogicznej literatury francuskiej, włoskiej i polskiej oraz omówiła zagadnienia takie jak: rodzina, szkoła, praca w dzieciństwie czy czas zabawy. Referat Leszka Kopciucha Biografia własna i cudza jako źródło kształtowania wrażliwości aksjologicznej ukazuje wpływ własnych i cudzych doświadczeń życiowych na kształtowanie osoby. Na końcu odnajdujemy pytanie warte przemyślenia: „jak zapanować nad własnym 
życiowym doświadczeniem?" (s. 57). Pierwszą część książki kończy artykuł Liliany Tomaszewskiej Uczenie się codzienności. Sensowność życia i przyjaźń kategorie (nie) codzienne. Autorka wskazuje na potrzebę posiadania sensu życia człowieka, bo dzięki temu można spełniać siebie. Omawia także codzienność społeczną w wymiarze osobistym i społecznym, jak również analizuje problematykę przyjaźni, która scala ludzi i która „(...) może być trampoliną do właściwych stosunków społecznych (...)” (s. 72).

Część drugą otwiera referat Hanny Solarczyk - Szwec Uczyć się przez całe życie: stary paradygmat $w$ nowej szacie pojęć? Autorka przedstawia rozwój edukacji ustawicznej na przestrzeni XX wieku. Ewa Wiśniewska w swoim artykule Studia podyplomowe forma edukacji ustawicznej nauczycieli przedstawia genezę i źródła edukacji ustawicznej oraz efektywność jej form, jak również funkcje, cele studiów podyplomowych, podstawy prawne i organizacyjne studiów podyplomowych dla nauczycieli. W kolejnym artykule Uczenie się jako priorytet edukacyjny? Małgorzata Kamińska - Juckiewicz podejmuje się próby odpowiedzi na pytania dotyczących kształcenia w polskich szkołach, zmian jakie należałoby wprowadzić oraz poszukiwania rozwiązań, co do skuteczności procesu uczenia się w społeczeństwie informacyjnym. Zofia Aleksandra Tomaszewska w referacie Uczenie się przez całe życie jako główna kompetencja współczesnego człowieka opisuje kluczową kompetencję człowieka, jaką jest uczenie się przez całe życie oraz instytucje edukacyjne, które wpływają na rozwój owej kompetencji. Jacek Znyk w artykule Znaczenie kształcenia ustawicznego w rozwoju wspótczesnego społeczeństwa opisuje kształcenie ustawiczne: jego zasady, cechy, funkcje, formy i metody. Dokonuje również charakterystyki „dojrzałego ucznia”. W referacie, kończącym część drugą książki, Marlena Karaś i Dorota Staszak próbują przekonać czytelników, że edukacja całożyciowa jest kluczem do bram XXI wieku. Część trzecia recenzowanej książki składa się z siedmiu artykułów, które dotyczą namysłu nad cudzą biografią. Pierwszy z nich powstał na podstawie badań terenowych przeprowadzonych w lipcu 2010 roku na terenie Żuław Elbląskich wśród najstarszego pokolenia nauczycieli (s. 164). Autor chciał uchwycić relacje między rodzicami a dzieckiem, nauczycielami a uczniami oraz pokazać znaczenie szkoły w integracji społeczności lokalnej i zaprezentować ścieżki zawodowe nauczycieli żuławskich . Kolejny referat poświęcony został druhowi Wacławowi Milke - pedagogowi i mentorowi wielu Płocczan. Marzena Brzózka przedstawia biografię tego wybitnego pedagoga, który był $\mathrm{n}$ animatorem harcerstwa, założycielem Harcerskiego Zespołu Pieśni i Tańca „Dzieci Płocka”, wielokrotnie odznaczanym za swoje zasługi. Następny artykuł dotyczy wspomnień pani Jadwigi Siniarskiej - Czaplickiej 
i ma na celu zwrócenie uwagi na rolę pamiętnika w poznawaniu historii: ludzi, kraju, miejsc, tradycji, strojów, wydarzeń, emocji itp. Maciej Kołodziejski w swoim tekście snuje refleksję na temat rozwoju muzycznego dziecka w pierwszym roku życia.

Kolejny artykuł dotyczy wychowania do starości jako wyrazu troski o jakość życia na emeryturze. Autorka - Dorota Zawadzka - ukazuje, że przygotowanie do starości powinno odbywać się na kilku poziomach, a efektem takiej edukacji ma być doprowadzenie jednostki do zrozumienia zmieniającej się sytuacji. Referat Jana R. Kalinowskiego Działalność społeczna jako jedna z dróg życiowych przyszłego pedagoga na przykładzie stowarzyszenia „Silni Razem" w Płocku przedstawia sposób działania stowarzyszenia i pokazuje, że działalność przygotowuje i daje praktyczne podstawy do pracy pedagoga poprzez kształtowanie poczucia odpowiedzialności za drugiego człowieka. Kończący trzecią i zarazem ostatnią część książki artykuł dotyczy biografii Dietricha Bonhoeffera. Autor zaprezentował także ideę bezreligijnego chrześcijaństwa i jej pedagogiczne walory. Prezentowana książka stanowi nowe źródło wiedzy na temat edukacji jako całożyciowego doświadczenia. Autorzy poruszą kwestie niezmiernie istotne, szczególnie w pracy każdego nauczyciela. Poszczególne artykuły potwierdzają konieczność ciągłego dokształcania i doskonalenia. Dzięki logicznemu i przejrzystemu układowi czytelnik znajdzie dla siebie inspirujący i ciekawy artykuł, który pomoże mu zrozumieć sens całożyciowego kształcenia oraz skłonić do autorefleksji nad własną praktyką i działalnością zawodową. Cele postawione przez autorów zostały zrealizowane, a przedstawione zagadnienia zostały ukazane w sposób czytelny. Recenzowana monografia napisana jest przystępnym i zrozumiałym językiem. Wszystkie teksty znajdujące się w recenzowanej książce są interesujące i godne polecenia, nie tylko studentom pedagogiki, ale również wszystkim przyszłym i obecnym nauczycielom. Zaletą tej publikacji jest to, że prowokuje ona do dalszej dyskusji na temat edukacji traktowanej jako całożyciowe doświadczenie. 